\title{
Impact of exogenous a-amylases on sugar formation in straight dough wheat bread
}

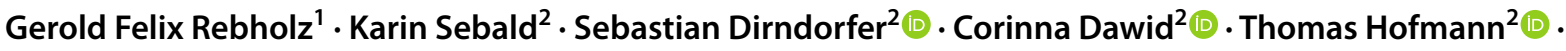 \\ Katharina Anne Scherf ${ }^{1,3}$ (1)
}

Received: 12 October 2020 / Revised: 9 November 2020 / Accepted: 14 November 2020 / Published online: 15 December 2020

(C) The Author(s) 2020

\begin{abstract}
The use of bacterial or fungal $\alpha$-amylases is common in wheat bread production to improve several quality-related parameters such as loaf volume, crust color or staling behavior. To study the impact of exogenous $\alpha$-amylases on straight dough wheat bread, we quantitated mono-, di- and oligosaccharides and residual $\alpha$-amylase activity in bread crumb during storage for up to $96 \mathrm{~h}$. Discovery-driven proteomics of the five $\alpha$-amylase preparations studied showed that only a few different amylases per preparation were responsible for the hydrolytic effect. Compared to the control, the supplementation with $\alpha$-amylase from Bacillus amyloliquefaciens in wheat dough preparation led to major changes in the sugar composition of bread crumb during storage with the formation of oligosaccharides like maltopentaose, maltohexaose, maltoheptaose, and maltooctaose. A residual activity corresponding to $4.0 \%$ of the applied activity was determined in the breads prepared with $\alpha$-amylase from $B$. amyloliquefaciens, but no residual activity was detected for any of the other fungal or bacterial $\alpha$-amylases from Aspergillus oryzae or Thermoactinomyces vulgaris. Whether the detected residual activity is related to the characteristics of bread staling or bread crumb properties must be clarified in further studies.
\end{abstract}

Keywords Amylase $\cdot$ Bread $\cdot$ Enzymatic activity $\cdot$ Maltose $\cdot$ Oligosaccharides $\cdot$ Wheat

\section{Introduction}

Amylases are present endogenously in wheat flour, but their activities vary greatly depending on the type and variety of grain, the environmental conditions during cultivation, and the state of maturity at harvest [1]. It is generally accepted that the amount of amylases present endogenously in wheat flour is too low to have a technological impact during the manufacturing of wheat bread except in cases of pre-harvest

Katharina Anne Scherf

katharina.scherf@kit.edu

1 Leibniz-Institute for Food Systems Biology at the Technical University of Munich, Lise-Meitner-Strasse 34, 85354 Freising, Germany

2 Chair of Food Chemistry and Molecular Sensory Science, TUM School of Life Sciences, Technical University of Munich, Lise-Meitner-Strasse 34, 85354 Freising, Germany

3 Department of Bioactive and Functional Food Chemistry, Institute of Applied Biosciences, Karlsruhe Institute of Technology (KIT), Adenauerring 20 a, 76131 Karlsruhe, Germany sprouting or late-maturity amylase activity. Considerable levels of $\beta$-amylase are present in unmalted wheat flour, while its $\alpha$-amylase content and associated activity are low. $\alpha$-Amylases (EC 3.2.1.1) are the most widely used enzymes in baking and play an important role due to their multiple quality-related functions in baking technology [2]. The quality-improving effect of the different $\alpha$-amylases used in baking is mainly based on their influence on the fermentation process, the influence on chemical reactions during baking leading to color and aroma formation and/or antistaling mechanisms [3, 4].

$\alpha$-Amylases predominantly catalyze endohydrolysis of $\alpha-(1-4)$-D-glycosidic bonds in the amylose and amylopectin molecules of wheat starch, but may also act as $\alpha$-exoamylase, generating $\alpha$-maltose from the non-reducing end. Thus, $\alpha$-amylases cause an increased release of $\alpha$-configured glucose, maltose, and oligosaccharides of varying length resulting in changes in the starch structure [5]. The addition of $\alpha$-amylase to wheat doughs improves the fermentation rate by providing additional substrates such as maltose and maltooligosaccharides to the yeast cells. This leads to a prolongation of the productive fermentation due to the fact that 
these sugars can be fermented by yeast shifting from glucose to maltose metabolism $[6,7]$.

In addition, the sugars formed by the hydrolytic activity of amylase can be substrates in various taste and aroma stimuli forming reactions. Especially, the caramelization process, the Maillard reaction, and the Strecker degradation are reactions that take place during the baking process under the influence of heat and in the presence of various reducing sugars. They are mainly responsible for the flavor and taste of wheat bread [8].

The action of $\alpha$-exo-amylases on the amylose and amylopectin molecules has a major impact on the staling properties of wheat bread. The degradation of the amylopectin side chains by $\alpha$-amylase hinders starch recrystallization and thus reduces the firming rate of starch [9]. Thermostable and intermediate temperature stability bacterial $\alpha$-amylase had an antistaling effect due to its ability to decrease the double-helical ordering of the starch matrix and this hindered starch retrogradation [10]. In addition to the antistaling effect resulting from the action on the three-dimensional structure of starch, $\alpha$-amylase might show an antistaling effect due to the release of oligosaccharides from starch [11]. Oligosaccharides with an average degree of polymerization of 5.1-6.2 for Bacillus subtilis $\alpha$-amylase and with 2.6-2.8 for Geobacillus stearothermophilus maltogenic $\alpha$-amylase might act as antiplasticizers, which reduce the mobility of amylopectin side chains and hinder the formation of double helices. However, despite a high amount of oligosaccharides, recrystallization was hardly reduced in wheat bread crumb [12].

During the baking process, the amylases are first reversibly unfolded and converted into an inactive state. In the second step after extended heat exposure, the proteins are irreversibly denatured [13]. The kinetics of inactivation is strongly correlated to the water content and heating rate in bread [14]. It is known that amylase from B. subtilis and $G$. stearothermophilus might be partly active after baking in wheat bread crumb, whereas the thermal stability of fungal amylase is lower than that of cereal amylase $[15,16]$.

In the European Union the use of enzymes in food production must be in compliance with the Regulation (EC) 1332/2008 [18]. In consideration of the Regulation (EU) No $1169 / 2011$ on the provision of food information to consumers, enzymes used as processing aid are not classified as food ingredients [19]. Thus, they do not have to be labeled. In the case of residual activity of enzymes in food, it must be clarified if the residual activity has a technological function in the final product. If there is a technological function in food, the enzymes are classified as ingredients and have to be labeled $[18,19]$

In our study, we focused on the impact of exogenous $\alpha$-amylases in straight dough wheat bread making. The main goal was to elucidate the relationship between the composition of commercial $\alpha$-amylase preparations, changes in bread during storage and possible residual activity of the enzyme. Via label-free discovery-driven mass spectrometry, we aimed to identify and quantitate $\alpha$-amylase in common preparations used in baking. By monitoring mono-, di- and oligosaccharides in the bread we got insights into the saccharide composition and its development during storage. The combination of these two methods with a colorimetric assay for the activity in bread after baking gave information about the cause and effect of molecular changes related to residual amylolytic activity in straight dough wheat bread.

\section{Materials and methods}

\section{Chemicals and flours}

All chemicals and solvents were at least HPLC-grade or higher. Water was purified using an Arium 611VF water purification system (Sartorius, Goettingen, Germany). Trypsin (from bovine pancreas, TPCK-treated, $\geq 10,000$ BAEE U/mg protein), sodium hydroxide solution (50-52\%), and anhydrous sodium acetate ( $\geq 99 \%)$ were obtained from SigmaAldrich (Steinheim, Germany). $\alpha$-Amylase assay reagent (4-nitrophenyl $\alpha$-D-maltoheptaoside (blocked), plus excess $\alpha$-glucosidase and glucoamylase) and $\beta$-amylase assay reagent (4-nitrophenyl $\beta$-D-maltotrioside, plus excess thermostable $\beta$-glucosidase) were purchased from Megazyme (Bray, Ireland). D-(+)-glucose ( $\geq 99.5 \%)$, D-(-)-fructose $(\geq 99 \%)$, sucrose $(\geq 99.5 \%)$, maltose monohydrate $(\geq 99 \%)$, maltotriose $(\geq 90 \%)$, and maltoheptaose $(\geq 70 \%)$ were obtained from Sigma-Aldrich. Maltotetraose ( $\geq 97 \%)$, maltopentaose $(\geq 90 \%)$, maltohexaose $(\geq 95 \%)$ and maltooctaose $(\geq 80 \%)$ were purchased from Santa Cruz (Dallas, USA). Wheat flour type 550 was provided by Rosenmühle (Ergolding, Germany).

\section{Amylase preparations}

Five different $\alpha$-amylase preparations commonly applied in bread making were used. The enzymes originated from Bacillus amyloliquefaciens (A), Thermoactinomyces vulgaris (B), and Aspergillus oryzae (C, D and $\mathrm{E})$. The preparations, their ingredients and dosage specified by the manufacturer are listed in Table 1 . The activity was determined by means of the $\alpha$-amylase assay procedure described below.

\section{Enzyme extraction from amylase preparations and determination of the protein content}

The amylase from the preparations was extracted according to Uhr et al. [19]. A sample quantity corresponding to $0.5 \mathrm{~g}$ of dry matter was extracted using $5.0 \mathrm{~mL}$ of extraction 
Table 1 Composition of the enzyme preparations as indicated by the manufacturer, dosage recommended by the manufacturer, and activity of the amylase added to the dough

\begin{tabular}{llllc}
\hline Preparation & Enzyme & Other ingredients & $\begin{array}{l}\text { Dosage }[\mathrm{mg} / \mathrm{kg} \\
\text { based on flour }]\end{array}$ & $\begin{array}{l}\text { Activity } \\
{\left[\mathrm{nkat} / \mathrm{g}_{\mathrm{dm}}\right]}\end{array}$ \\
\hline (A) & Bacterial $\alpha$-amylase & Wheat starch, edible oil & 50 & 1.77 \\
(B) & Bacterial $\alpha$-amylase & Wheat flour, sunflower oil & 600 & 62.74 \\
(C) & Fungal $\alpha$-amylase & Wheat flour, wheat starch, dextrin & 10 & 6.52 \\
(D) & Fungal $\alpha$-amylase & Wheat flour, dextrin & 25 & 77.39 \\
(E) & Fungal $\alpha$-amylase & Wheat flour & 50 & 27.08 \\
\hline
\end{tabular}

buffer $(0.1 \mathrm{~mol} / \mathrm{L}$ ammonium bicarbonate, $4.0 \mathrm{~mol} / \mathrm{L}$ urea, and $0.005 \mathrm{~mol} / \mathrm{L}$ dithiothreitol (DTT) $(\mathrm{pH} 8.0)$ in water). The extraction procedure was performed at room temperature by stirring for $30 \mathrm{~min}$. Following the extraction step, the extract was centrifuged $\left(20 \mathrm{~min} ; 20^{\circ} \mathrm{C} ; 3750 \times g\right)$ and the supernatant was collected for further analysis.

The proteins were quantitated in the extracts of the preparations by an RP-HPLC method using a Jasco-XLC System (Jasco, Pfungstadt, Germany) with an Acclaim $300 \mathrm{C}_{18}$ column ( $3 \mu \mathrm{m}$ particle size, $30 \mathrm{~nm}$ pore size, $2.1 \mathrm{~mm} \times 150 \mathrm{~mm}$; Thermo Fisher Scientific, Waltham, USA) equipped with a security guard ultra column of the same type. The column temperature was $60{ }^{\circ} \mathrm{C}$; the injection volume was $10 \mu \mathrm{L}$. Elution solvents were (A) $0.1 \%$ aqueous trifluoroacetic acid (TFA) and (B) acetonitrile containing 0.1\% TFA. A linear gradient was applied as follows: $0.0 \mathrm{~min}, 0 \% \mathrm{~B} ; 0.4 \mathrm{~min}$ $0 \% \mathrm{~B}, 0.5 \mathrm{~min}, 24 \% \mathrm{~B} ; 15.0 \mathrm{~min}, 56 \% \mathrm{~B} ; 15.1 \mathrm{~min}, 90 \%$ $\mathrm{B} ; 19.1 \mathrm{~min}, 90 \% \mathrm{~B} ; 19.2 \mathrm{~min}, 0.0 \% \mathrm{~B} ; 35.0 \mathrm{~min}, 0.0 \% \mathrm{~B}$. The flow rate was $0.2 \mathrm{~mL} / \mathrm{min}$. Detection was carried out by measuring the UV absorbance at $210 \mathrm{~nm}$ [21]. Control of the system and the evaluation of the chromatograms were done with the software ChromPass (Jasco). Quantitation of the protein content of the samples was performed by means of external calibration using reference gliadin from the Working Group on Prolamin Analysis and Toxicity (PWG-gliadin) [22]. All determinations were done in triplicate.

\section{Sample preparation for ultra-high-performance liquid chromatography time-of-flight mass spectrometry (UHPLC-TOF-MS)}

Amylase from wheat flour and from the preparations was extracted according to Uhr et al. [19]. Following the extraction and centrifugation an appropriate volume of the supernatant was diluted to a protein content of $0.5 \mathrm{mg} / \mathrm{mL}$ in $0.3 \mathrm{~mL}$ and $0.1 \mathrm{~mL}$ Tris- $\mathrm{HCl}(1.5 \mathrm{~mol} / \mathrm{L})$ and $0.1 \mathrm{~mL}$ 1-propanol was added. Reduction was performed by adding $0.05 \mathrm{~mL}$ tris(2-carboxyethyl)phosphine $(0.05 \mathrm{~mol} / \mathrm{L}$ tris $(2-$ carboxyethyl)phosphine in $0.5 \mathrm{~mol} / \mathrm{L}$ Tris-HCL, $\mathrm{pH} 8.5$ ) and incubating for $30 \mathrm{~min}$ at $60{ }^{\circ} \mathrm{C}$. The cysteine residues of the proteins were alkylated using $0.1 \mathrm{~mL}$ chloroacetamide solution $(0.5 \mathrm{~mol} / \mathrm{L}$ chloroacetamide in $0.5 \mathrm{~mol} / \mathrm{L}$ Tris- $\mathrm{HCl}, \mathrm{pH} 8.5$ ) per sample for $45 \mathrm{~min}$ at $37{ }^{\circ} \mathrm{C}$ in the dark. After the alkylation step, the samples were evaporated to dryness using a rotary vacuum concentrator $\left(37^{\circ} \mathrm{C}, 3 \mathrm{~h}\right.$, $800 \mathrm{~Pa}$ ). Tryptic hydrolysis was carried out by reconstitution of the samples in $0.5 \mathrm{~mL}$ trypsin stock solution with trypsin:substrate ratio of 1:20 (w/w) $(0.04 \mathrm{~mol} / \mathrm{L}$ urea in $0.1 \mathrm{~mol} / \mathrm{L}$ Tris- $\mathrm{HCl}, \mathrm{pH} 7.8$ ). The samples were incubated at $37{ }^{\circ} \mathrm{C}$ for $16 \mathrm{~h}$. Hydrolysis was stopped by heating the samples at $95{ }^{\circ} \mathrm{C}$ for $8 \mathrm{~min}$. Following the tryptic digestion, the samples were purified via solid-phase extraction using 100 mg Discovery DSC-18 tubes (Merck, Darmstadt, Germany). The tubes were activated using methanol (1 mL), equilibrated with acetonitrile/water/formic acid (FA) (80:20:0.1; $1 \mathrm{~mL}$ ) and washed with acetonitrile/water/FA (2:98:0.1; $5 \times 1 \mathrm{~mL})$. After washing the tubes, the samples were loaded on the tubes and the cartridges were washed again as described before. Elution of the peptides was performed with acetonitrile/water/FA (40:60:0.1). The eluate was dried using a rotary vacuum concentrator $\left(37^{\circ} \mathrm{C}, 4 \mathrm{~h}\right.$, $800 \mathrm{~Pa})$, reconstituted in $500 \mu \mathrm{L} \mathrm{FA}$ and filtered $(0.45 \mu \mathrm{m}$; wwPTFE). The analysis of three independent technical replicates each confirmed that the chosen workflow led to reproducible results in terms of confident qualitative peptide and protein identification.

\section{Discovery-driven proteomics using UHPLC-TOF-MS}

UHPLC-TOF-MS measurements were carried out on a Sciex TripleTOF 6600 mass spectrometer (Sciex, Darmstadt, Germany) connected to a Shimadzu Nexera X2 system (Shimadzu, Kyoto, Japan) operating in the positive electrospray ionization (ESI) mode. Control of the instrument and data acquisition were performed using AnalystTF software (Version 1.7.1, Sciex). Chromatography was performed on a $150 \times 2.1 \mathrm{~mm}, 1.6 \mu \mathrm{m}$ BioZen Peptide PS-C ${ }_{18}$ LC column (Phenomenex, Aschaffenburg, Germany) equipped with a security guard ultra column $(2 \times 2.1 \mathrm{~mm})$ of the same type. Elution solvents were (A) $1 \%$ aqueous FA and (B) acetonitrile containing $1 \% \mathrm{FA}$. The gradient was performed at a flow rate of $0.35 \mathrm{~mL} / \mathrm{min}$ starting at $0 \mathrm{~min}, 5 \% \mathrm{~B} ; 5 \mathrm{~min}$, $5 \% \mathrm{~B} ; 60 \mathrm{~min}, 40 \% \mathrm{~B} ; 65 \mathrm{~min}, 100 \% \mathrm{~B} ; 69 \mathrm{~min}, 100 \% \mathrm{~B}$; $70 \mathrm{~min}, 5 \% \mathrm{~B}$; and $75 \mathrm{~min}, 5 \% \mathrm{~B}$. The temperature of the column oven was set to $40{ }^{\circ} \mathrm{C}$, the injection volume was $10 \mu \mathrm{L}$. 
For the experiments, the ion spray voltage was set at $5500 \mathrm{eV}$, the source temperature was $550{ }^{\circ} \mathrm{C}$, the nebulizing gas was at 55 psi, the heating gas was at 65 psi and nitrogen served as curtain gas at 35 psi.

In the information-dependent acquisition mode (IDA), a TOF-MS survey scan was acquired from $\mathrm{m} / \mathrm{z}, 400$ to 1000 using an accumulation time of $250 \mathrm{~ms}$, collision energy (CE) of $10 \mathrm{~V}$ and a declustering potential (DP) of $80 \mathrm{~V}$. Product ion spectra for the 12 most abundant compounds were recorded in the high-resolution mode for $70 \mathrm{~ms}$ within the $\mathrm{m} / \mathrm{z}$ range of $100-2000$ using a DP of $80 \mathrm{~V}$ and CE of $40 \mathrm{~V}$, with CE spread of $15 \mathrm{~V}$. IDA criteria for the precursor ion included intensity of $>100$ counts/s. Q1 resolution was set to $0.7 \mathrm{Da}$.

\section{Protein identification using MaxQuant}

A search workflow using MaxQuant (version 1.6.10.43) was developed for the identification and relative quantitation of proteins (Fig. 1). The MS raw files were used as input in the MaxQuant software for different searches against databases derived from UniProtKB. The first step of data evaluation was the identification of enzymes from the class of glycosylases (EC 3.2.-.-). A database was built with all proteins belonging to the class EC 3.2.-.- from Triticum aestivum and from 14 microorganisms relevant for the production of food-grade amylases according to the European Food Safety Authority and the US Food and Drug Administration $[23,24]$. This resulted in a database containing 5550 proteins (Download: 01.07.2019). To identify all possible proteins present in the sample, in the second step a database containing the proteome of the identified organisms was used, respectively. In the final third step, the relative quantitation of the proteins was performed using the intensity based absolute quantitation (iBAQ) algorithm implemented within MaxQuant. Via iBAQ, the iBAQ intensities of different proteins within one sample can directly be compared to each other, and the relative concentrations of proteins can be determined [25]. Therefore, for each sample, an individual database was built containing all the identified proteins from the second step. A total sum normalization of iBAQ protein intensities between samples was performed to correct for different total protein injection amounts. The parameters were set as follows for all MaxQuant searches: Variable modification included oxidation of methionine and $\mathrm{N}$-terminal protein acetylation. Carbamidomethylation on cysteines was specified as fixed modifications. Trypsin was set as a proteolytic enzyme with up to two allowed missed cleavage sites. Match-between-runs was enabled with a matching time window of $0.7 \mathrm{~min}$ and an alignment time window of $20 \mathrm{~min}$. Results were filtered for a minimal length of five amino acids and $1 \%$ peptide and protein false discovery rate.

\section{Baking experiments}

Baking experiments were performed on a $50 \mathrm{~g}$ flour scale. The baking recipe was: Wheat flour type $550(50 \mathrm{~g}$, based on $14 \%$ moisture), $2.0 \mathrm{~g}$ baking soda, $0.25 \mathrm{~g}$ sodium chloride,

Sample preparation \& LC-MS/MS

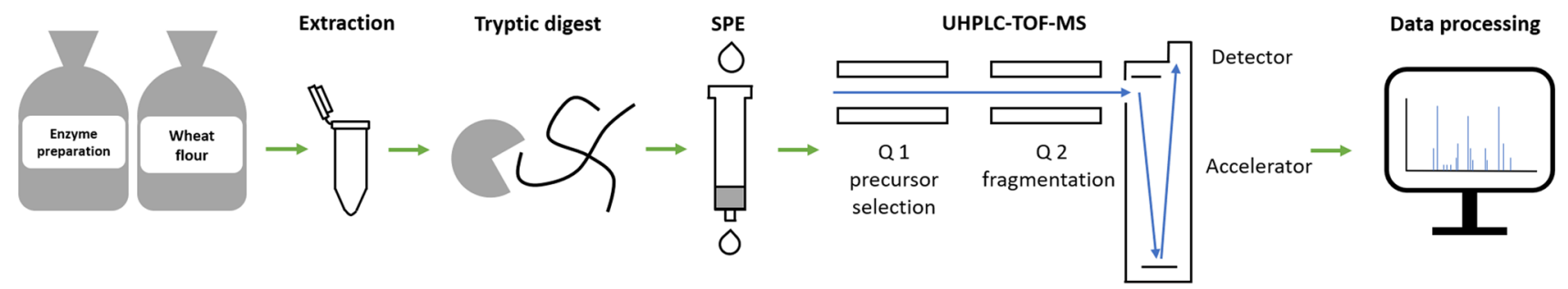

Data evaluation
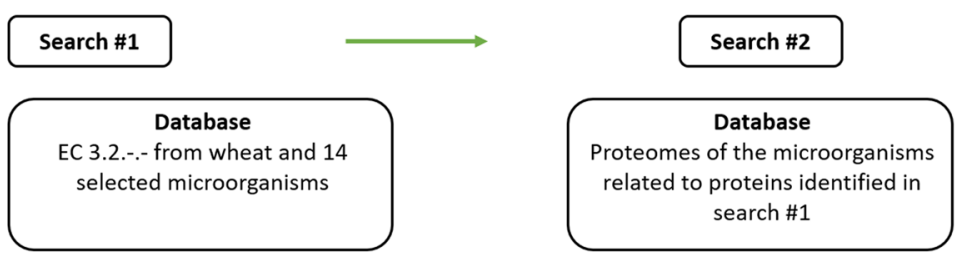

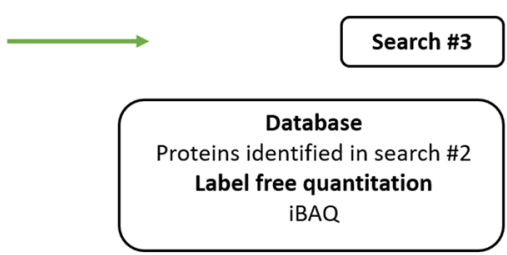

Fig. 1 Workflow illustrating the procedure from sample preparation to UHPLC-TOF-MS analysis and data evaluation using three subsequent search strategies to identify the peptides and the corresponding proteins present in the amylase preparations and the wheat flour.
iBAQ, intensity-based absolute quantitation; SPE, solid-phase extraction; UHPLC-TOF-MS, ultra-high-performance liquid chromatography time-of-flight mass spectrometry 
bulk liquid as determined in the Farinograph-E [26]. To obtain a $\mathrm{pH}$ comparable to yeast-leavened wheat bread $(\mathrm{pH}$ 6) water as the bulk liquid was replaced by a buffer solution with $0.1 \mathrm{~mol} / \mathrm{L}$ citric acid monohydrate and $0.1 \mathrm{~mol} / \mathrm{L}$ trisodium citrate dihydrate $(\mathrm{pH} 2.75)$. Baking soda was added $1 \mathrm{~min}$ before the end of the kneading time. The amylase preparation was added to the dough in powder form and dosed as shown in Table 1. The dough was kneaded in the Farinograph-E at 60 rounds per min to optimum consistency [26]. After kneading the dough was rounded for eight cycles and placed in the proofing cabinet, where the first dough rest took place for $20 \mathrm{~min}$ in a water-saturated atmosphere at $30{ }^{\circ} \mathrm{C}$. Then, the dough piece was rolled (roll gap: $0.8 \mathrm{~cm}$ ), folded into half, rounded for five cycles, and put into an aluminium baking pan. The second dough rest was performed for 40 min under the same conditions as for the first dough rest. Baking took place in a deck oven Type-9110-0082 (Binder, Tuttlingen, Germany) at $230^{\circ} \mathrm{C}$ for $18 \mathrm{~min}$.

For the determination of the amylase activity in bread all experiments were carried out in triplicate. The breads were stored for $30 \mathrm{~h}$ at $22{ }^{\circ} \mathrm{C}$ under vacuum. The breads used for the sugar identification and quantitation were either extracted directly after cooling $(2 \mathrm{~h})$ or stored under vacuum for up to $96 \mathrm{~h}$ at $22^{\circ} \mathrm{C}$. These baking experiments were carried out in fourfold determination.

\section{Determination of amylase activity}

Extraction of $\alpha$-amylase was performed according to Cornaggia et al. [27]. The amylase preparations or bread ( $1.0 \mathrm{~g}$ dry matter) were extracted each with $10 \mathrm{~mL}$ extraction buffer $(0.1 \mathrm{~mol} / \mathrm{L}$ sodium maleate, $\mathrm{pH} 5.5,1.0 \mathrm{mg} / \mathrm{mL}$ bovine serum albumin, $0.025 \mathrm{~mol} / \mathrm{L}$ DTT) for $16 \mathrm{~h}$ at $22{ }^{\circ} \mathrm{C}$. After centrifugation $\left(10 \mathrm{~min} ; 20^{\circ} \mathrm{C} ; 2500 \times g\right)$ and filtration $(0.45 \mu \mathrm{m}$; cellulose acetate) an aliquot $(0.1 \mathrm{~mL})$ of the supernatant was used to determine the $\alpha$-amylase activity with the Ceralpha Method (Megazyme). The supernatant as well as the $\alpha$-amylase substrate, containing 4-nitrophenyl- $\beta$-Dmaltoside and a thermostable $\beta$-glucosidase, were preincubated at $40{ }^{\circ} \mathrm{C}$. For the assay, the preincubated supernatant and $0.1 \mathrm{~mL}$ of preincubated substrate were mixed and incubated for $60 \mathrm{~min}$ at $40{ }^{\circ} \mathrm{C}$. The assay was stopped by adding $1.5 \mathrm{~mL}$ of $20 \%(\mathrm{w} / \mathrm{v})$ tri-sodium phosphate buffer (pH 11). Release of 4-nitrophenyl was measured spectrophotometrically at $400 \mathrm{~nm}$. A solution of $1.5 \mathrm{~mL} \mathrm{20 \% (w/v)}$ tri-sodium phosphate buffer ( $\mathrm{pH} 11), 0.1 \mathrm{~mL}$ substrate and $0.1 \mathrm{ml}$ enzyme extract was used as blank. $\alpha$-Amylase activity was expressed in nkat $/ \mathrm{g}_{\mathrm{dm}}$. One kat is defined as the amount of 4-nitrophenol in mol released from the substrate non reducing-end blocked 4-nitrophenylmaltoheptaoside in one second under the assay conditions. All enzyme extractions as well as determinations of $\alpha$-amylase activity were performed with three technical replicates.

\section{Extraction, identification, and quantitation of mono-, di-, and oligosaccharides from wheat flour, dough and bread}

Breadcrumb (0.5 g dry matter) was extracted using $4.0 \mathrm{~mL}$ of $50 \%(\mathrm{v} / \mathrm{v})$ methanol while stirring for $30 \mathrm{~min}$ at $22{ }^{\circ} \mathrm{C}$. The suspension was centrifuged for $20 \mathrm{~min}$ and $20^{\circ} \mathrm{C}$ at $3500 \times g$. The supernatant was dried using a rotary vacuum concentrator $\left(37^{\circ} \mathrm{C}, 9 \mathrm{~h}, 800 \mathrm{~Pa}\right)$ to remove the solvent. The samples were reconstituted in $1.0 \mathrm{~mL}$ deionized water and purification of the extracts was performed using strongcation exchange columns (StrataX-C $33 \mu \mathrm{m}, 200 \mathrm{mg}, 3 \mathrm{~mL}$, Phenomenex). The columns were activated with methanol $(1 \times 3.0 \mathrm{~mL})$, equilibrated and washed with $0.1 \%(\mathrm{v} / \mathrm{v}) \mathrm{FA}$ $(3 \times 3.0 \mathrm{~mL})$. After loading the sample, the sugars were eluted with $0.1 \%(\mathrm{v} / \mathrm{v})$ FA $(2 \times 2.0 \mathrm{~mL})$. The eluent was removed using a rotary vacuum concentrator and the sugars redissolved in deionized water.

Mono-, di-, and oligosaccharides were analysed by highperformance anion exchange chromatography with pulsed amperometric detection (HPAEC-PAD) on a Dionex ICS5000 system (Thermo Fisher Scientific) equipped with a CarboPac PA-100 column $(250 \times 4 \mathrm{~mm})$ connected to a CarboPac PA-100 guard column $(50 \times 4 \mathrm{~mm})$. The flow rate was $1.0 \mathrm{~mL} / \mathrm{min}$. Solvent A was $1.0 \mathrm{~mol} / \mathrm{L}$ sodium acetate solution, solvent B $1.0 \mathrm{~mol} / \mathrm{L}$ sodium hydroxide solution and solvent C: deionized water. Solvent B was set to $15 \%$ for the total run time. The gradient was $0 \mathrm{~min}, 0.5 \% \mathrm{~A} ; 2 \mathrm{~min}, 0.5 \%$ A; 8 min, $10 \%$ A; 18 min, $20 \%$ A; 23 min, $20 \%$ A; 24 min, $0.5 \% \mathrm{~A} ; 39 \mathrm{~min}, 0.5 \% \mathrm{~A}$. The pulsed amperometric detector was equipped with a gold working electrode operating with a standard quadruple waveform. Data analysis was performed using Chromeleon software 7.2 (Thermo Fisher Scientific). Quantitation of the sugars was performed by means of external calibration with standard solutions. Concentration ranges for the calibration were as follows: glucose and fructose, $0.130-0.004 \mathrm{mg} / \mathrm{mL}$; sucrose and maltose, $0.100-0.003 \mathrm{mg} /$ $\mathrm{mL}$; maltotriose, $0.150-0.005 \mathrm{mg} / \mathrm{mL}$; maltotetraose, $0.130-0.004 \mathrm{mg} / \mathrm{mL}$; maltopentaose, $0.180-0.006 \mathrm{mg} /$ $\mathrm{mL}$; maltohexaose, $0.160-0.005 \mathrm{mg} / \mathrm{mL}$; maltoheptaose, $0.180-0.006 \mathrm{mg} / \mathrm{mL}$; maltooctaose, $0.130-0.004 \mathrm{mg} / \mathrm{mL}$.

\section{Statistical analysis}

The sugar content of the bread samples is presented as mean value \pm standard deviation. To account for the data dependency within each bread sample and to investigate differences of the sugar contents across time points $(2 \mathrm{~h}, 22 \mathrm{~h}, 48 \mathrm{~h}$, and $96 \mathrm{~h}$ after baking) linear mixed models were used. $P$-values were adjusted for multiple testing across time points by the Bonferroni procedure. Statistical analyses were performed with R statistical software (Vienna, Austria). 


\section{Results}

\section{Protein identification and composition of the amylase preparations}

Both bacterial $\alpha$-amylase preparations (A) and (B) contained one $\alpha$-amylase each. In the three fungal preparations (C), (D) and (E) one $\alpha$-amylase (D9J2M5) and one glucoamylase (EC 3.2.1.3, A0A1S9DG38), both from A. oryzae, were identified (Table 2). Other proteins from the enzyme group of glycosylases (EC 3.2) were not identified in the bacterial or fungal preparations. The protein composition of the amylase preparations is shown in Fig. 2. Preparation (A) consisted of $85.0 \% \alpha$-amylase P00692. The amount of $\alpha$-amylase A0A0N0H9C2 in (B) was $21.1 \%$. Both preparations contained various proteins from the respective organism B. amyloliquefaciens (A) and T. vulgaris (B) (1.6\% (A),
$6.1 \%$ (B)). Wheat proteins were present additionally to the microbial proteins. They were grouped into gluten proteins and other wheat proteins. Preparation (A) contained 13.4\% other wheat proteins, whereas (B) contained $38.7 \%$ other wheat proteins and $34.1 \%$ gluten proteins.

The composition of the fungal $\alpha$-amylase preparations (C), (D) and (E) was similar in terms of the protein groups. The relative percentage of the fungal $\alpha$-amylase D9J2M5 was $73.4 \%$ in (C), $53.7 \%$ in (D) and $79.4 \%$ in (E). Compared to D9J2M5 the percentage of glucoamylase A0A1S9DG38 was low: preparations (C) and (D) contained $0.3 \%$, respectively, and (E) $0.2 \%$. The total amount of other A. oryzae proteins was $4.0 \%$ for (C), $1.4 \%$ for (D) and $1.2 \%$ for (E), in which A0A1S9DG38 was included due to the low relative percentage. Other wheat proteins were present with $15.4 \%$ in (C), $16.8 \%$ in (D) and $9.1 \%$ in (E) and gluten proteins with $7.2 \%$ in $(\mathrm{C}), 28.1 \%$ in (D) and $10.2 \%$ in (E).
Table 2 Amylases identified in the preparations with their UniprotKB accession number, the number of peptides identified per amylase, the corresponding protein coverage and the organism to which the amylases were assigned

\begin{tabular}{llllll}
\hline Preparation & Protein & Enzyme & $\begin{array}{l}\text { No. of } \\
\text { peptides }\end{array}$ & Coverage [\%] & Organism \\
\hline (A) & P00692 & $\alpha$-Amylase & 33 & 72.6 & Bacillus amyloliquefaciens \\
(B) & A0A0N0H9C2 & $\alpha$-Amylase & 25 & 53.1 & Thermoactinomyces vulgaris \\
(C) & D9J2M5 & $\alpha$-Amylase & 27 & 41.4 & Aspergillus oryzae \\
& A0A1S9DG38 & Glucoamylase & 13 & 21.7 & Aspergillus oryzae \\
(D) & D9J2M5 & $\alpha$-Amylase & 26 & 34.9 & Aspergillus oryzae \\
& A0A1S9DG38 & Glucoamylase & 12 & 21.6 & Aspergillus oryzae \\
(E) & D9J2M5 & $\alpha$-Amylase & 29 & 47.6 & Aspergillus oryzae \\
& A0A1S9DG38 & Glucoamylase & 11 & 21.9 & Aspergillus oryzae \\
\hline
\end{tabular}

All protein scores were $>150$
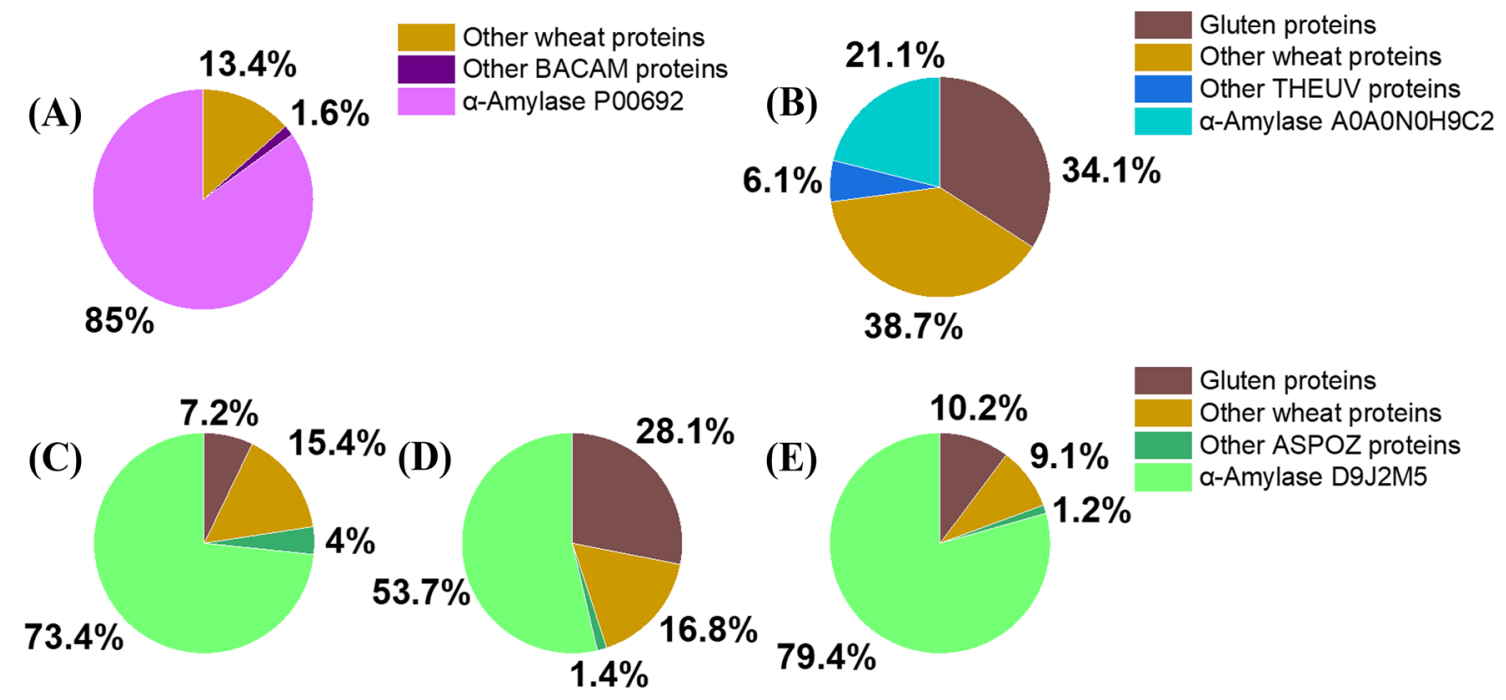

Fig. 2 Relative distribution of wheat and microbial proteins in the tested $\alpha$-amylase preparations based on MaxQuant iBAQ values. a Bacillus amyloliquefaciens (BACAM) preparation, b Thermoactinomyces vulgaris (THEUV) preparation, $\mathbf{c}-\mathbf{e}$ Aspergillus oryzae (ASPOZ) preparations 


\section{Sugar release during wheat bread storage by endogenous amylase}

The sugars glucose, fructose, sucrose, maltose, maltotriose, and maltotetraose were detected in the control breads without any exogenous amylase addition at $2 \mathrm{~h}, 24 \mathrm{~h}$ and $48 \mathrm{~h}$ after the end of the baking process (Fig. 3). Neither the qualitative nor the quantitative sugar composition in the bread changed during the first $48 \mathrm{~h}$ of storage. The average quantity of total sugar was $27.6 \mathrm{mg} / \mathrm{g}_{\mathrm{dm}}( \pm 4.5)$, with maltose as the predominant sugar in the breads $\left(14.6 \mathrm{mg} / \mathrm{g}_{\mathrm{dm}}( \pm 1.1)\right.$ $2 \mathrm{~h}$ after baking). Glucose and fructose were present in a similar quantity (glucose: $2.9 \mathrm{mg} / \mathrm{g}_{\mathrm{dm}}( \pm 0.6)$ and fructose: $\left.2.8 \mathrm{mg} / \mathrm{g}_{\mathrm{dm}}( \pm 2.0)\right)$ over $48 \mathrm{~h}$. The average quantity was $5.8 \mathrm{mg} / \mathrm{g}_{\mathrm{dm}}( \pm 0.8)$ for sucrose, $1.5 \mathrm{mg} / \mathrm{g}_{\mathrm{dm}}( \pm 0.1)$ for maltotriose and $1.1 \mathrm{mg} / \mathrm{g}_{\mathrm{dm}}( \pm 0.3)$ for maltotetraose.

\section{Sugar release during wheat bread storage by exogenous amylases}

In the breads manufactured with the addition of preparation (A), glucose, fructose, sucrose, maltose and maltotriose were detected $2 \mathrm{~h}$ after baking (Fig. 4). Further, maltotetraose was identified $22 \mathrm{~h}$ after baking and maltopentaose, maltohexaose, maltoheptaose and maltooctaose were present in the sample $48 \mathrm{~h}$ after baking. Two hours after baking $13.1 \mathrm{mg} / \mathrm{g}_{\mathrm{dm}}( \pm 3.0)$ glucose, $24.8 \mathrm{mg} / \mathrm{g}_{\mathrm{dm}}( \pm 4.6)$ fructose and $13.8 \mathrm{mg} / \mathrm{g}_{\mathrm{dm}}( \pm 3.5)$ sucrose were measured in the bread. The total content of mono-, di-, and oligosaccharides was $140.5 \mathrm{mg} / \mathrm{g}_{\mathrm{dm}}( \pm 5.0) 2 \mathrm{~h}$ after baking. The amounts of these sugars did not change significantly during the total storage time of $96 \mathrm{~h}$. The maltotriose content increased significantly,

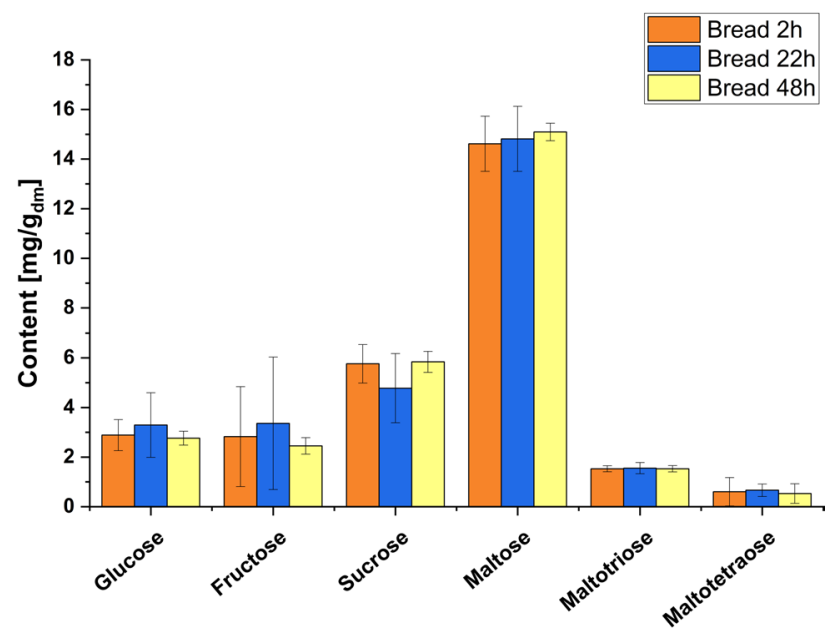

Fig. 3 Sugar content of control breads manufactured without addition of exogenous $\alpha$-amylase. Samples were taken $2 \mathrm{~h}, 22 \mathrm{~h}$ and $48 \mathrm{~h}$ after baking. Values are displayed as means \pm standard deviation $(n=4)$. There were no significant differences within each sugar between the different time points

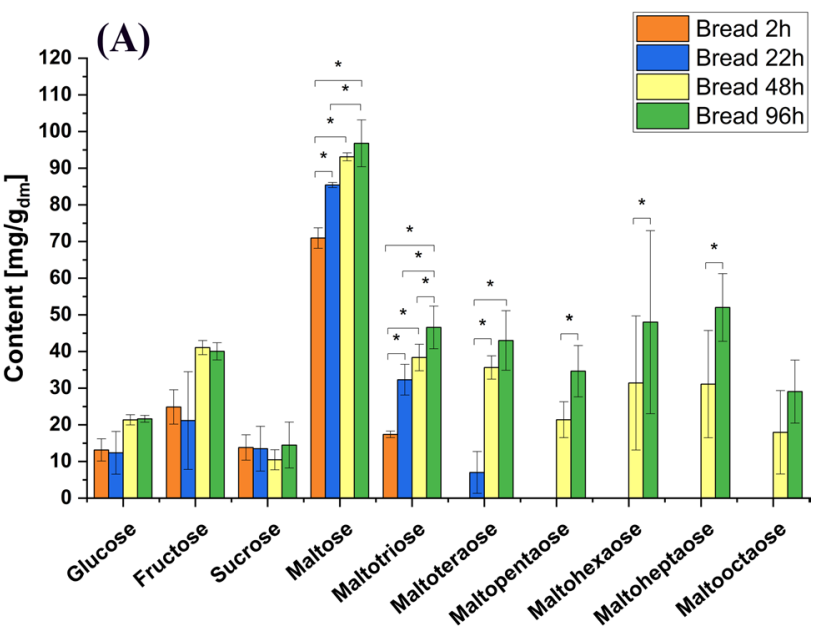

Fig. 4 Sugar content of model breads manufactured with the addition of (A), $\alpha$-amylase preparation containing $\alpha$-amylase from Bacillus amyloliquefaciens. Samples were taken 2 h, 22 h, 48 h and 96 h after baking. Values are displayed as means \pm standard deviation $(n=4)$. Significant differences between the different time points for each sugar are indicated by asterisks $(p<0.05)$

starting at $17.4 \mathrm{mg} / \mathrm{g}_{\mathrm{dm}}( \pm 0.9) 2 \mathrm{~h}$ after baking to $32.3 \mathrm{mg} /$ $\mathrm{g}_{\mathrm{dm}}( \pm 4.2) 22 \mathrm{~h}$ after baking, and from $38.3 \mathrm{mg} / \mathrm{g}_{\mathrm{dm}}( \pm 3.6)$ $48 \mathrm{~h}$ to $46.6 \mathrm{mg} / \mathrm{g}_{\mathrm{dm}}( \pm 5.8) 96 \mathrm{~h}$ after baking. Maltotetraose increased significantly from $6.9 \mathrm{mg} / \mathrm{g}_{\mathrm{dm}}( \pm 5.7) 22 \mathrm{~h}$ after baking to $43.0 \mathrm{mg} / \mathrm{g}_{\mathrm{dm}}( \pm 8.1)$ at $96 \mathrm{~h}$. Furthermore, the contents of the sugars identified and quantitated for the first time at $48 \mathrm{~h}$ of storage increased significantly until $96 \mathrm{~h}$ of storage: Maltopentaose increased from $21.4 \mathrm{mg} / \mathrm{g}_{\mathrm{dm}}$ $( \pm 4.9)$ to $34.6 \mathrm{mg} / \mathrm{g}_{\mathrm{dm}}( \pm 7.0)$, maltohexaose from $31.40 \mathrm{mg} /$ $\mathrm{g}_{\mathrm{dm}}( \pm 18.3)$ to $48.0 \mathrm{mg} / \mathrm{g}_{\mathrm{dm}}( \pm 25.0)$, maltoheptaose from $31.1 \mathrm{mg} / \mathrm{g}_{\mathrm{dm}}( \pm 14.6)$ to $52.0 \mathrm{mg} / \mathrm{g}_{\mathrm{dm}}( \pm 9.2)$. The increase of maltooctaose from $17.9 \mathrm{mg} / \mathrm{g}_{\mathrm{dm}}( \pm 11.4)$ to $29.1 \mathrm{mg} / \mathrm{g}_{\mathrm{dm}}$ $( \pm 8.6)$ was not significant.

In the breads manufactured with (B), the composition of the sugar spectrum did not change significantly during the first $48 \mathrm{~h}$ of storage (Fig. 5). The total sugar content at $2 \mathrm{~h}$ was $44.4 \mathrm{mg} / \mathrm{g}_{\mathrm{dm}}( \pm 3.0)$. The glucose content of the breads increased significantly from $4.2 \mathrm{mg} / \mathrm{g}_{\mathrm{dm}}( \pm 0.5)$ at $2 \mathrm{~h}$ of storage to $5.6 \mathrm{mg} / \mathrm{g}_{\mathrm{dm}}( \pm 1.1)$ at $48 \mathrm{~h}$ of storage. Further, fructose increased significantly in the first $48 \mathrm{~h}$ of storage from $9.5 \mathrm{mg} / \mathrm{g}_{\mathrm{dm}}( \pm 1.2)$ to $12.4 \mathrm{mg} / \mathrm{g}_{\mathrm{dm}}( \pm 2.5)$ and maltose increased from $20.3 \mathrm{mg} / \mathrm{g}_{\mathrm{dm}}( \pm 1.2)$ to $24.7 \mathrm{mg} / \mathrm{g}_{\mathrm{dm}}( \pm 1.3)$. Between the time points $22 \mathrm{~h}$ and $48 \mathrm{~h}$ of storage no significant changes were detected for all sugars.

For the three fungal $\alpha$-amylase preparations (Fig. 6) glucose, fructose, sucrose, maltose, and maltotriose could be identified in the breads. Except for (D), maltotetraose was identified. In general, no significant changes in sucrose were identified for all three preparations. Further, the use of the preparation (C) did not result in significant changes in the contents of glucose, fructose, maltose, and maltotriose. With 


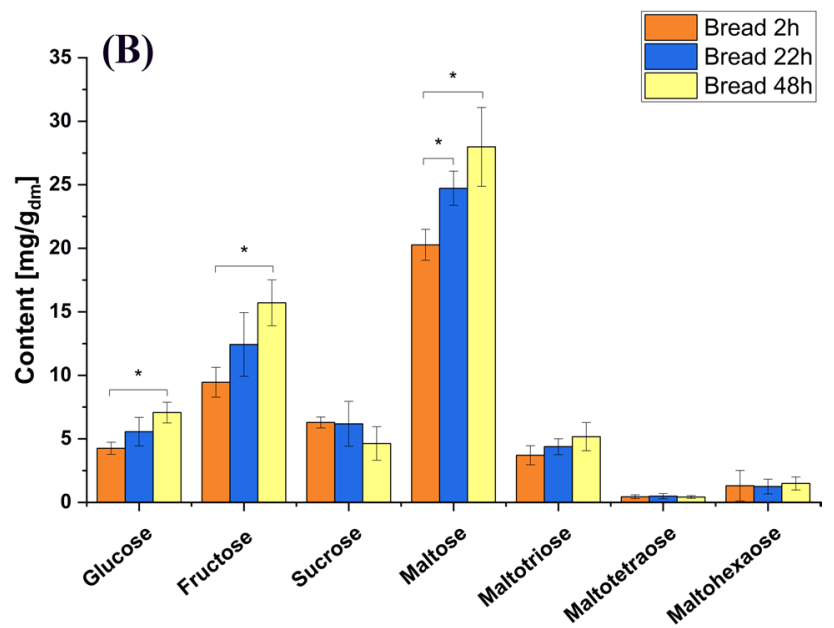

Fig. 5 Sugar content of model breads manufactured with the addition of (B), $\alpha$-amylase preparation containing $\alpha$-amylase from Thermoactinomyces vulgaris. Samples were taken 2 h, 22 h, 48 h, and $96 \mathrm{~h}$ after baking. Values are displayed as means \pm standard deviation $(n=4)$. Significant differences between the different time points for each sugar are indicated by asterisks $(p<0.05)$ the application of (D) no maltotetraose was formed during bread processing. For preparation (D), significant increases were monitored during the $96 \mathrm{~h}$ of storage in glucose, fructose, and maltose contents. Glucose increased from $7.8 \mathrm{mg} /$ $\mathrm{g}_{\mathrm{dm}}( \pm 0.4)$ at $2 \mathrm{~h}$ of storage to $11.4 \mathrm{mg} / \mathrm{g}_{\mathrm{dm}}( \pm 1.0)$ at $96 \mathrm{~h}$ of storage, fructose increased from $15.0 \mathrm{mg} / \mathrm{g}_{\mathrm{dm}}( \pm 1.2)$ at $2 \mathrm{~h}$ to $21 \mathrm{mg} / \mathrm{g}_{\mathrm{dm}}( \pm 1.8)$ at $96 \mathrm{~h}$ and maltose as the predominant sugar increased from $26.5 \mathrm{mg} / \mathrm{g}_{\mathrm{dm}}( \pm 1.3)$ to $37.9 \mathrm{mg} / \mathrm{g}_{\mathrm{dm}}$ $( \pm 1.9)$ at $96 \mathrm{~h}$. The average total sugar content was $91.0 \mathrm{mg} /$ $\mathrm{g}_{\mathrm{dm}}( \pm 7.0)$ for $(\mathrm{C})$ and $55.0 \mathrm{mg} / \mathrm{g}_{\mathrm{dm}}( \pm 2.2)$ for $(\mathrm{D}) 2 \mathrm{~h}$ after the end of the baking process.

The application of preparation (E) led to an amount of total sugar in bread of $92.8 \mathrm{mg} / \mathrm{g}_{\mathrm{dm}}( \pm 3.0)$ and showed similar changes as (D). The amount of glucose present in the bread manufactured with (E) at $2 \mathrm{~h}$ increased significantly from $5.4 \mathrm{mg} / \mathrm{g}_{\mathrm{dm}}( \pm 0.7)$ to $23.5 \mathrm{mg} / \mathrm{g}_{\mathrm{dm}}( \pm 1.4)$ at $96 \mathrm{~h}$ of storage. Fructose increased from $9.1 \mathrm{mg} / \mathrm{g}_{\mathrm{dm}}( \pm 1.9)$ at $2 \mathrm{~h}$ to $37.3 \mathrm{mg} / \mathrm{g}_{\mathrm{dm}}( \pm 1.6)$ at $96 \mathrm{~h}$; maltose increased from $52.2 \mathrm{mg} / \mathrm{g}_{\mathrm{dm}}( \pm 1.7)$ to $85.2 \mathrm{mg} / \mathrm{g}_{\mathrm{dm}}( \pm 2.6)$ in the same time period.
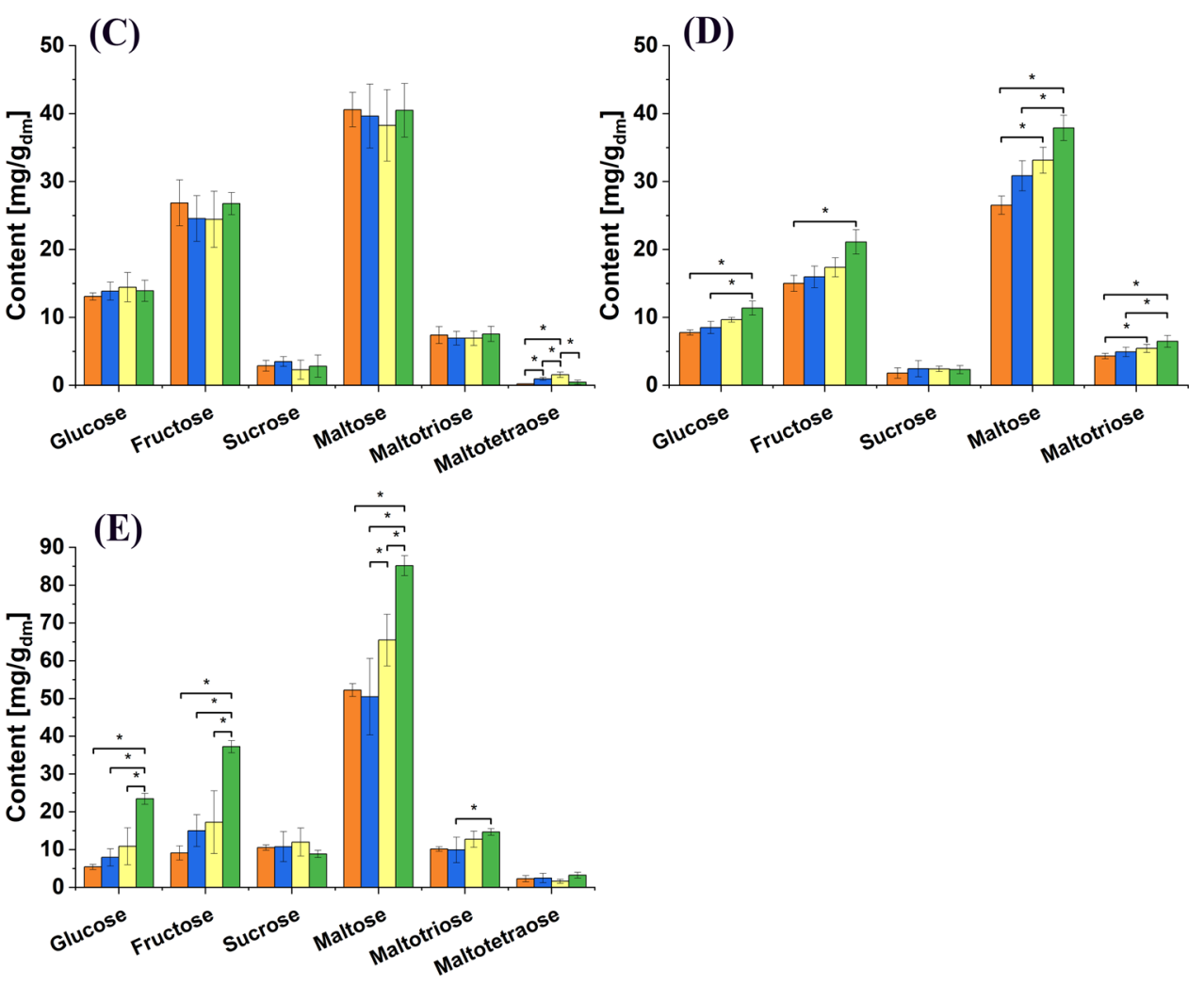

Fig. 6 Sugar content of model breads manufactured with the addition of fungal $\alpha$-amylase preparations (C), (D) and (E) containing $\alpha$-amylase from Aspergillus oryzae. Samples were taken 2 h, 22 h,
$48 \mathrm{~h}$, and $96 \mathrm{~h}$ after baking. Significant differences between the different time points for each sugar are indicated by asterisks $(p<0.05)$ 


\section{Residual activity of a-amylases in model toast bread}

In the wheat flour used for the baking experiments, the activity of endogenous $\alpha$-amylase was $4.11 \mathrm{nkat} / \mathrm{g}_{\mathrm{dm}}( \pm 0.65)$. After baking, no activity of endogenous $\alpha$-amylase was detected in the crumb of the control breads.

The activity of exogenous $\alpha$-amylases applied in the baking experiments was based on the dosage recommendations of the manufacturers of the preparations. The activity applied to the dough (Table 1) was $1.77 \mathrm{nkat} / \mathrm{g}_{\mathrm{dm}}( \pm 0.03)$ for preparation (A), $62.74 \mathrm{nkat} / \mathrm{g}_{\mathrm{dm}}( \pm 2.40)$ for preparation (B), $6.52 \mathrm{nkat} / \mathrm{g}_{\mathrm{dm}}( \pm 1.67)$ for $(\mathrm{C}), 77.39 \mathrm{nkat} / \mathrm{g}_{\mathrm{dm}}( \pm 20.83)$ for (D) and $27.08 \mathrm{nkat} / \mathrm{g}_{\mathrm{dm}}( \pm 1.64)$ for $(\mathrm{E})$.

For preparation (B) and the fungal preparations (C), (D) and (E) no activity in the crumb of the model toast breads was detected after baking. For preparation (A) an activity of $0.07 \mathrm{nkat} / \mathrm{g}_{\mathrm{dm}}( \pm 0.02)$ was detected. This corresponded to residual activity of $4.01 \%$ in relation to the activity applied to the dough under the selected parameters of dough production and baking.

\section{Discussion}

In the present study, we applied a discovery-driven proteomics strategy combined with monitoring of enzymatic hydrolysis products and the quantitation of amylase residual activity in bread to get new insights into the complexity of enzymatic mechanisms in toast bread manufacturing.

The approach using discovery-driven proteomics underlined that amylase preparations used in baking generally contain a small number of functional proteins responsible for the hydrolytic activity of the preparation. This was also shown before by Picariello et al. and Prandi et al. [28, 29]. The iBAQ evaluation is suitable for the relative quantitation of several different proteins in one sample $[25,30]$ and it showed differences in the protein composition between the preparations. The proportion of $\alpha$-amylase in the bacterial preparations (A) and (B) was $21.1 \%$ and $85.0 \%$, respectively. In preparation (B) gluten proteins and other wheat proteins were detected, indicating that wheat flour was used as filler material. Only non-gluten proteins were present in preparation (A). In particular, the protein P27736, which is a starch synthase and present in wheat starch, shows that (A) contained wheat starch as filler material [31]. The fungal preparations had a similar composition and besides 53.7-79.4\% of $\alpha$-amylase, the other ingredients were wheat flour and various Aspergillus proteins.

The baking experiments were carried out without yeast fermentation in a simplified model bread because we intended to focus on differentiating the action of endogenous wheat amylases from exogenous microbial amylases and study the specific changes caused by each of these preparations. Adding yeast with its associated diverse enzymatic activity would have added a potential confounding factor. Due to their sensitivity to heat, the yeast enzymes are unlikely to influence the sugar composition during storage, rather during dough preparation and the early stages of baking. Further experiments would be necessary to study the exact influence of using exogenous microbial amylases in yeast-leavened breads and see how the sugar composition is affected in general. A novel approach using a gas-free crumb pellet system already demonstrated that firming kinetics appeared to be unaffected by the leavening method [32].

The control breads showed no significant changes in the sugar profile during the first $48 \mathrm{~h}$ storage. In accordance with Struyf et al. [7], amylase addition in wheat bread-making had a major impact on the maltose levels of dough and bread. Maltose was the sugar found in the highest concentrations in the control breads as well as in the breads with bacterial or fungal $\alpha$-amylase. For all preparations, the amounts of maltose in bread were higher than in the control bread. Preparation (A) led to an increase in maltose of $385.6 \%$ compared to the control breads, which was the largest impact on the maltose content in this study. The maltose content of the breads stored for $2 \mathrm{~h}$ and baked with the addition of (B) showed the smallest increase (39.0\%) compared to the control bread. All fungal preparations showed different changes in maltose content, which was about $80.1-257.5 \%$ higher in the breads with fungal amylase addition compared to the control bread. This could imply that all amylases had at least some exo-activity, but an increased maltose content can also be caused by endo-amylase activity because more non-reducing ends are generated that are susceptible to subsequent $\beta$-amylase attack [6].

Two hours after baking a total sugar content between $44.4 \mathrm{mg} / \mathrm{g}_{\mathrm{dm}}( \pm 3.0)$ for (B) and $140.5 \mathrm{mg} / \mathrm{g}_{\mathrm{dm}}( \pm 5.0)$ for $(\mathrm{A})$ was observed. Hence, the impact of the preparation on the sugar content is highly dependent on the amylase applied. However, considering the impact of the three fungal preparations on the total sugar content of the breads, we showed that the effect of the same protein could be different: The total sugar content was $91.0 \mathrm{mg} / \mathrm{g}_{\mathrm{dm}}( \pm 7.0)$ for $(\mathrm{C}), 54.9 \mathrm{mg} / \mathrm{g}_{\mathrm{dm}}$ $( \pm 2.22)$ for (D) and $92.8 \mathrm{mg} / \mathrm{g}_{\mathrm{dm}}( \pm 3.0)$ for $(\mathrm{E})$. There was no correlation between the applied $\alpha$-amylase activity and the magnitude of change of the sugar spectrum between the breads.

The main difference between the bacterial preparations (A) and (B) regarding the sugar spectrum was the occurrence of new oligosaccharides: maltopentaose, maltohexaose, maltoheptaose and maltooctaose were detected for the first time at $48 \mathrm{~h}$ of storage. In addition, a significant increase of $167.8 \%$ in maltotriose content between 2 and $96 \mathrm{~h}$ after baking was observed $\left(17.4 \mathrm{mg} / \mathrm{g}_{\mathrm{dm}}\right.$ to $\left.46.6 \mathrm{mg} / \mathrm{g}_{\mathrm{dm}}\right)$. Maltotetraose was detected after $22 \mathrm{~h}$ of storage with $7.0 \mathrm{mg} / \mathrm{g}_{\mathrm{dm}}$ and its content increased by $514.3 \%$ to $43.0 \mathrm{mg} / \mathrm{g}_{\mathrm{dm}}$ after 
$96 \mathrm{~h}$ of storage. These maltooligosaccharides, which were formed during storage in considerable amounts, are typical products of $\alpha$-amylase activity [33]. The effect of new sugars occurring after $48 \mathrm{~h}$ of storage was not observed for preparation (B). Furthermore, no significant changes in maltotriose and maltotetraose were observed during the $48 \mathrm{~h}$ of storage. For (A), a residual activity of $0.07 \mathrm{nkat} / \mathrm{g}_{\mathrm{dm}}$, corresponding to $4.01 \%$ of the applied activity of $1.77 \mathrm{nkat} / \mathrm{g}_{\mathrm{dm}}$, was determined in the assay, as expected based on previous reports on its temperature stability [34]. By checking the signal-to-noise ratio of the assay, the extinction value corresponding to the residual activity of $0.07 \mathrm{nkat} / \mathrm{g}_{\mathrm{dm}}$ was proven to be valid. There was no direct relation between the amount of sugar produced during storage and the residual activity [nkat], defined as mol substrate turnover per second. Enzymatic activity in bread is a function of many factors in the enzyme environment including but not limited to the concentration of the substrate, the concentration of the product, the mobility of the enzyme or substrate, the presence of inhibitors, the $\mathrm{pH}$ value, and the temperature. However, the temperature optimum of $\alpha$-amylase from $B$. amyloliquefaciens is $70{ }^{\circ} \mathrm{C}$ and it still shows activity at $90^{\circ} \mathrm{C}$ [34]. Thus, the changes in maltotriose and maltotetraose as well as the release of new sugars after $48 \mathrm{~h}$ can be explained by enzymatic activity. Further research is required to investigate the stability of this enzyme in the bread matrix.

Both preparations (A) and (B) showed an increase in maltose, which was significant during the first $48 \mathrm{~h}$ of storage. For (A), it was $22.2 \mathrm{mg} / \mathrm{g}_{\mathrm{dm}}$ corresponding to $31.3 \%$ and for (B), it was $7.7 \mathrm{mg} / \mathrm{g}_{\mathrm{dm}}$ or $37.9 \%$. Due to the lack of residual activity for the $T$. vulgaris $\alpha$-amylase in preparation (B) this effect cannot be caused by residual activity. The changes in maltose content may be related to changes in the extractability of sugars from bread due to starch retrogradation. Lin and Lineback [35] also showed that the amount of extractable maltooligosaccharides in wheat bread without and with the addition of $\alpha$-amylase changed during 6 days of storage, but they did not propose a mechanism on a molecular level. More recently, several mechanisms on how mono-, di- and oligosaccharides influence starch gelatinization have been discussed based on water activity, glass transition temperatures, and intermolecular hydrogen bonding [36]. The denaturation and melting behavior of biopolymers, like starch, in the presence of plasticizers such as sugars and polyols was found to be related to the effective molar density of hydroxyl groups available for intermolecular hydrogen bonding, also designated as effective solvent volume fraction [37]. This term was found to describe gelatinization in ternary starch/sugar/water mixtures and it was linked to the volumetric density of intermolecular hydrogen bonds [38]. Therefore, it might be possible that hydrogen bonds between starch and sugars are weakened during retrogradation and lead to a change in the extractability of sugars over time.
Because the overall sugar contents in the control bread were considerably lower than in the breads with enzyme addition, the changes in extractability are expected to be smaller.

All fungal $\alpha$-amylase preparations (C), (D) and (E) showed no residual activity in the assays performed. Fungal $\alpha$-amylase showed a lower inactivation temperature than bacterial $\alpha$-amylase at about $80{ }^{\circ} \mathrm{C}$ [16]. Despite the irreversible inactivation of the $\alpha$-amylase from $A$. oryzae in preparations (C), (D) and (E), significant changes in the sugar spectrum of the breads manufactured with the preparations (D) and (E) were observed. In the breads manufactured with the respective preparation, glucose, fructose, and maltose content significantly increased during the $96 \mathrm{~h}$ of storage. It may be possible that the change in the sugar spectrum without a measurable residual amylase activity is related to changes in the extractability of sugars caused by starch retrogradation [35].

\section{Conclusion}

Five different $\alpha$-amylase preparations commonly applied in bread production were analyzed regarding their protein composition and their impact on straight dough wheat breads. We identified three $\alpha$-amylases of different origins in the sample set. Preparation (A) with $\alpha$-amylase from $B$. amyloliquefaciens showed the largest impact on the total sugar content of bread, with an increase of $408.6 \%$ compared to the control (at $2 \mathrm{~h}$ ). The fungal preparations did not show a uniform impact on the total sugar content with increases ranging from 99.0 to $229.6 \%$ compared to the control. Residual activity of $0.07 \mathrm{nkat} / \mathrm{g}_{\mathrm{dm}}$ corresponding to $4.01 \%$ of the applied activity was determined in the breads of preparation (A). This resulted in a significant increase of maltotriose and maltotetraose during storage as well as the formation of new sugars, but we cannot conclude whether the residual activity measured after extraction from the crumb of baked bread has any technological function on the bread during storage. Our proteomics-based approach coupled with the quantitation of sugars and the detection of residual activity in bread allowed observing the activity of exogenous enzymes in straight dough wheat bread during storage for the first time.

Acknowledgements The authors thank Stefanie Hackl and Angelika Grassl for excellent technical assistance, Dr. Sabrina Geisslitz (KIT) for helpful discussions, and Dr. Leonie Weinhold (IMBIE, University Hospital Bonn) for advice on statistical evaluation.

Author contributions Conceptualization: GFR, KAS; methodology: GFR, KAS; formal analysis, investigation: GFR, KS, SD; writingoriginal draft, visualization: GFR; writing-review and editing: KS, $\mathrm{SD}, \mathrm{CD}$, TH, KAS; resources: $\mathrm{CD}$, TH; supervision, project administration: KAS. 
Funding Open Access funding enabled and organized by Projekt DEAL. This IGF Project of the FEI was supported via AiF within the programme for promoting the Industrial Collective Research (IGF) of the German Ministry of Economic Affairs and Energy (BMWi), based on a resolution of the German Parliament. Project AiF 19543N.

\section{Compliance with ethical standards}

Conflict of interest The authors declare no competing financial interest.

Human and animal rights statement This article does not contain any studies with human or animal subjects.

Open Access This article is licensed under a Creative Commons Attribution 4.0 International License, which permits use, sharing, adaptation, distribution and reproduction in any medium or format, as long as you give appropriate credit to the original author(s) and the source, provide a link to the Creative Commons licence, and indicate if changes were made. The images or other third party material in this article are included in the article's Creative Commons licence, unless indicated otherwise in a credit line to the material. If material is not included in the article's Creative Commons licence and your intended use is not permitted by statutory regulation or exceeds the permitted use, you will need to obtain permission directly from the copyright holder. To view a copy of this licence, visit http://creativecommons.org/licenses/by/4.0/.

\section{References}

1. Dupont FM, Altenbach SB (2003) Molecular and biochemical impacts of environmental factors on wheat grain development and protein synthesis. J Cereal Sci 38:133-146. https://doi. org/10.1016/S0733-5210(03)00030-4

2. Whitehurst RJ, van Oort M (eds) (2010) Enzymes in food technology. Wiley-Blackwell, Chichester, pp 109-111

3. Bosmans GM, Lagrain B, Fierens E, Delcour JA (2013) Impact of amylases on biopolymer dynamics during storage of straightdough wheat bread. J Agric Food Chem 61:6525-6532. https:// doi.org/10.1021/jf402021g

4. Jiménez T, Martínez-Anaya MA (2001) Amylases and hemicellulases in breadmaking. Degradation by-products and potential relationship with functionality. Food Sci Technol Int 7:5-14. https ://doi.org/10.1106/7U5G-5AKQ-HVBQ-4XA0

5. Tebben L, Shen Y, Li Y (2018) Improvers and functional ingredients in whole wheat bread: a review of their effects on dough properties and bread quality. Trends Food Sci Technol 81:10-24. https://doi.org/10.1016/j.tifs.2018.08.015

6. Struyf N, Verspreet J, Courtin CM (2016) The effect of amylolytic activity and substrate availability on sugar release in nonyeasted dough. J Cereal Sci 69:111-118. https://doi.org/10.1016/j. jes.2016.02.016

7. Struyf N, Verspreet J, Verstrepen KJ, Courtin CM (2017) Investigating the impact of $\alpha$-amylase, $\alpha$-glucosidase and glucoamylase action on yeast-mediated bread dough fermentation and bread sugar levels. J Cereal Sci 75:35-44. https://doi.org/10.1016/j. jcs.2017.03.013

8. Cho IH, Peterson DG (2010) Chemistry of bread aroma: a review. Food Sci Biotechnol 19:575-582. https://doi.org/10.1007/s1006 8-010-0081-3
9. Hug-Iten S, Fischer F, Conde-Petit B (2001) Structural properties of starch in bread and bread model systems: Influence of an antistaling alpha-amylase. Cereal Chem 78:421-428

10. Palacios HR, Schwarz PB, D’Appolonia BL (2004) Effect of alpha-amylases from different sources on the retrogradation and recrystallization of concentrated wheat starch gels: relationship to bread staling. J Agric Food Chem 52:5978-5986. https://doi. org/10.1021/jf030377z

11. Defloor I, Delcour JA (1999) Impact of maltodextrins and antistaling enzymes on the differential scanning calorimetry staling endotherm of baked bread doughs. J Agric Food Chem 47:737-741. https://doi.org/10.1021/jf9806356

12. Goesaert H, Leman P, Bijttebier A, Delcour JA (2009) Antifirming effects of starch degrading enzymes in bread crumb. J Agric Food Chem 57:2346-2355. https://doi.org/10.1021/jf803058v

13. Perdana J, Fox MB, Schutyser MAI, Boom RM (2012) Enzyme inactivation kinetics: coupled effects of temperature and moisture content. Food Chem 133:116-123. https://doi.org/10.1016/j.foodc hem.2011.12.080

14. Zhang L, Chen XD, Boom RM, Schutyser MAI (2017) Thermal inactivation kinetics of $\beta$-galactosidase during bread baking. Food Chem 225:107-113. https://doi.org/10.1016/j.foodc hem.2017.01.010

15. Lagrain B, Leman P, Goesaert H, Delcour JA (2008) Impact of thermostable amylases during bread making on wheat bread crumb structure and texture. Food Res Int 41:819-827. https:// doi.org/10.1016/j.foodres.2008.07.006

16. Cauvain S (2015) Technology of breadmaking. Springer International Publishing, Cham

17. Reichenberger K, Luz A, Seitl I, Fischer L (2020) Determination of the direct activity of the maltogenic amylase from Geobacillus stearothermophilus in white bread. Food Anal Methods 13:496502. https://doi.org/10.1007/s12161-019-01673-7

18. Regulation (EC) (2008) No 1332/2008 of the European Parliament and of the Council of 16 December 2008on food enzymes and amending Council Directive 83/417/EEC, Council Regulation (EC) No 1493/1999, Directive 2000/13/EC, Council Directive 2001/112/EC and Regulation (EC) No 258/9

19. Regulation (EU) (2011) No 1169/2011 of the European Parliament and of the Council of 25 October 2011 on the provision of food information to consumers, amending Regulations (EC) No 1924/2006 and (EC) No 1925/2006 of the European Parliament and of the Council, and repealing Commission Directive 87/250/EEC, Council Directive 90/496/EEC, Commission Directive 1999/10/EC, Directive 2000/13/EC of the European Parliament and of the Council, Commission Directives 2002/67/EC and 2008/5/EC and Commission Regulation (EC) No 608/200

20. Uhr L, Buchholz T, Homann T, Huschek G (2014) Targeted proteomics-based analysis of technical enzymes from fungal origin in baked products. J Cereal Sci 60:440-447. https://doi. org/10.1016/j.jcs.2014.04.007

21. Schalk K, Lexhaller B, Koehler P, Scherf KA (2017) Isolation and characterization of gluten protein types from wheat, rye, barley and oats for use as reference materials. PLoS ONE 12:e0172819. https://doi.org/10.1371/journal.pone.0172819

22. Van Eckert R, Berghofer E, Ciclitira PJ, Chirdo F, Denery-Papini S, Ellis HJ, Ferranti P, Goodwin P, Immer U, Mamone G, Méndez E, Mothes T, Novalin S, Osman A, Rumbo M, Stern M, Thorell L, Whim A, Wieser H (2006) Towards a new gliadin reference material-isolation and characterisation. J Cereal Sci 43:331-341. https://doi.org/10.1016/j.jcs.2005.12.009

23. European Food Safety Authority, Parma, IT (2019) https://www. efsa.europa.eu/de/search/site/amylase. Accessed 1 Jul 2019

24. Food and Drug Administration, Silver Spring, USA (2019) https:// search.usa.gov/search?query $=$ amylase $\&$ affiliate $=$ fda1. Accessed 1 Jul 2019 
25. Schwanhäusser B, Busse D, Li N, Dittmas G, Schuchhardt J, Wolf J, Chen W, Selbach M (2011) Global quantification of mammalian gene expression control. Nature 473:337-342. https://doi. org/10.1038/nature10098

26. Kieffer R, Wieser H, Henderson MH, Graveland A (1998) Correlations of the breadmaking performance of wheat flour with rheological measurements on a micro-scale. J Cereal Sci 27:53-60. https://doi.org/10.1006/jcrs.1997.0136

27. Cornaggia C, Evans DE, Draga A, Mangan D, McCleary BV (2019) Prediction of potential malt extract and beer filterability using conventional and novel malt assays. J Inst Brew 125:294309. https://doi.org/10.1002/jib.567

28. Picariello G, Di Stasio L, Mamone G, Iacomino G, Venezia A, Iannaccone N, Ferranti P, Coppola R, Addeo F (2018) Identification of enzyme origin in dough improvers: DNA-based and proteomic approaches. Food Res Int 105:52-58. https://doi. org/10.1016/j.foodres.2017.10.046

29. Prandi B, Lambertini F, Varani M, Faccini A, Suman M, Leorati A, Tedeschi T, Sforza S (2020) Assessment of enzymatic improvers in flours using LC-MS/MS detection of marker tryptic peptides. J Am Soc Mass Spectrom 31:240-248. https://doi. org/10.1021/jasms.9b00109

30. Geisslitz S, Ludwig C, Scherf KA, Koehler P (2018) Targeted LC-MS/MS reveals similar contents of $\alpha$-amylase/trypsin-inhibitors as putative triggers of nonceliac gluten sensitivity in all wheat species except einkorn. J Agric Food Chem 66:12395-12403. https://doi.org/10.1021/acs.jafc.8b04411

31. Ainsworth C, Clark J, Balsdon J (1993) Expression, organisation and structure of the genes encoding the waxy protein (granulebound starch synthase) in wheat. Plant Mol Biol 22:67-82

32. Paulik S, Jekle M (2019) Novel approach to investigate the mechanical properties of crumb matrix during storage-re-engineering of gas-free crumb pellets. Food Chem 288:333-340. https://doi.org/10.1016/j.foodchem.2019.03.014

33. van der Maarel MJEC, van der Veen B, Uitdehaag JCM, Leemhuis H, Dijkhuizen L (2002) Properties and applications of starch-converting enzymes of the $\alpha$-amylase family. J Biotechnol 94:137-155. https://doi.org/10.1016/S0168-1656(01)00407-2

34. Brzozowski AM, Lawson DM, Turkenburg JP, Bisgaard-Frantzen H, Svendsen A, Borchert TV, Dauter Z, Wilson KS, Davies GJ (2000) Structural analysis of a chimeric bacterial alpha-amylase. High-resolution analysis of native and ligand complexes. Biochemistry 39:9099-9107. https://doi.org/10.1021/bi0000317

35. Lin W, Lineback DR (1990) Changes in carbohydrate fractions in enzyme-supplemented bread and the potential relationship to staling. Starke 42:385-394

36. Allan MC, Rajwa B, Mauer LJ (2018) Effects of sugars and sugar alcohols on the gelatinization temperature of wheat starch. Food Hydrocoll 84:593-607. https://doi.org/10.1016/j.foodh yd.2018.06.035

37. Van der Sman RGM (2016) Sugar and polyol solutions as effective solvent for biopolymers. Food Hydrocoll 56:144-149. https://doi. org/10.1016/j.foodhyd.2015.12.001

38. Van der Sman RGM, Mauer LJ (2019) Starch gelatinization temperature in sugar and polyol solutions explained by hydrogen bond density. Food Hydrocoll 94:371-380. https://doi.org/10.1016/j. foodhyd.2019.03.034

Publisher's Note Springer Nature remains neutral with regard to jurisdictional claims in published maps and institutional affiliations. 